\title{
Development of Agroforestry-Based Ecotourism in RPH Mangunan, KPH Yogyakarta
}

\author{
Mega Lugina ${ }^{1}$, Indartik ${ }^{2}$, Mirna Aulia Pribadi ${ }^{3}$, Ari Wibowo ${ }^{4}$ \\ \{mega_lugina@yahoo.com ${ }^{1}$, indartik32@yahoo.co.id², auliamirna@gmail.com ${ }^{3}$ \} \\ Center for Research and Development of Socio-Economic Policy and Climate Change \\ Ministry of Environment and Forestry \\ Jl. Gunung Batu No. 5, Bogor-16118 Indonesia ${ }^{123}$
}

\begin{abstract}
Land management in RPH Mangunan which involves surrounding communities, are agroforestry and ecotourism. The development of ecotourism has made agroforestry less attractive, even though people have cultivated crops for a long time. The paper aims to design an agroforestry-based ecotourism model and calculate its financial analysis. The data analysis used is descriptive and financial analysis for the feasibility of an agroforestry-based ecotourism business in KPH area. The result shows that three tour operators in RPH Mangunan which are ready to be developed into agroforestry-based ecotourism namely, Bukit Pengger, Puncak Becici, and Pinus Sari. The appropriate agroforestry pattern is the development of guava and coffee plants in the tour area as part of ecotourism. From the calculation, planting guava giving a positive NPV of Rp. 5.53 million per ha and IRR of $42 \%$; while the development of coffee plants resulting in an NPV of Rp. 57.46 million per ha and IRR of $69 \%$.
\end{abstract}

Keywords: agroforestry, ecoturism, RPH Mangunan.

\section{Introduction}

Communities around the Forest Management Resort of Mangunan (RPH Mangunan) in Yogyakarta Forest Management Unit (KPH Yogyakarta) have links to forest both in the collection of non-timber forest products and the use of KPH area in the form of "tumpangsari". Limited community land ownership, lack of capital, low of education level, and limited ability; are causing the community to have a relatively high dependency on KPH area [1], [2]. KPH Yogyakarta accommodates community involvement in managing KPH land by allocating land to be managed jointly with surrounding communities. The current activities involving communities around forests in RPH Mangunan include the allocation of agroforestry/intercropping land and the development of ecotourism in protected areas. 
Agroforestry is an effective forest land use pattern that increases income and food production [3]. Annual plants under tree stands contribute to fulfilling people's daily needs both for their consumption and for sale. Relatively diverse agroforestry products increase small farmer resilience in facing crop failure and climate change [4]. In the KPH Yogyakarta forest area, there are some locations for agricultural cultivation on forest land in the form of agroforestry, which is managed by local communities to meet their daily need [2]. The development of ecotourism began when many people were attracted to the beauty of the pine forest in RPH Mangunan.

The development of ecotourism is one of the efforts to improve local livelihood and, this brings a contribution to forest conservation efforts as the community is more maintaining the presence of tree stands, which are the main objects in ecotourism. However, with the development of ecotourism, agroforestry activities have become less desirable, especially for young people who consider farming activities as an energy-intensive activity. Therefore, it is necessary to develop agroforestry in accordance with community preferences and in line with the development of ecotourism.

The management of ecotourism in RPH Mangunan is carried out by involving the surrounding communities, which is formed in a cooperative. The number of visitors who come is quite promising considering Yogyakarta Region is a tourist destination for both domestic and foreign visitors. Packaging the tourist attractions in RPH Mangunan is the primary key to develop the activity. At present, attractions that combine natural beauty with cultural offerings, especially the uniqueness of Yogyakarta culture, are the theme of tour offered at RPH Mangunan. The study aims to design an agroforestry-based ecotourism model and calculate its financial analysis.

\section{Method}

\subsection{Location}

Data collection at the Forest Management Resort of Mangunan (RPH Mangunan) in the Yogyakarta Forest Management Unit (KPH Yogyakarta) was conducted in September-December 2019. The activity of data and information collection included biophysical aspects as well as socio economic and policy aspects. The location of the study is focused on the Mangunan protection forest, managed by nine tour operators, namely: Seribu Batu, Pinus Sari, Pinus Asri, Lintang Sewu, Pintu Langit Dahromo, Puncak Becici, Bukit Pengger, Bukit Panguk, and Bukit Mojo. 


\subsection{Materials and Tools}

Data collection on the readiness of tour operators to develop agroforestrybased ecotourism is gained through in-depth interviews with tour operators and focus group discussion (FGD). The number of respondents representing tour operators amounted to 15 people. The first FGD was conducted by inviting all tour operators to determine the appropriate type of Multi-Purpose Tree Species (MPTS) to be developed in RPH Mangunan and mapping the readiness of tour operators to develop agroforestry-based ecotourism. The second FGD was conducted by inviting stakeholders involved in the management of ecotourism and resource persons from the Yogyakarta Agriculture Office to explain the cultivation of selected MPTS to be developed. The third FGD was conducted by inviting the three selected operators to discuss the development of agroforestry-based ecotourism. In order to identify visitors' preferences, interviews with visitors were conducted amounted to 70 respondents. Questionnaires were used as guidance in collecting data through surveys both for tour operators and visitors/tourists. Selected plant seedlings are the materials used in the development of agroforestry-based ecotourism.

\subsection{Logical Framework}

The utilization of the KPH area both for agroforestry and tourism brings livelihoods to local communities. Agroforestry activities also contribute to local food availability. Tourism activities in the RPH Mangunan area have increased people's awareness to protect forest stands, which are the main object of tourism activities. Local communities are willing to develop tourism in Mangunan. However, they have limited knowledge of tourism. Most of tour operators weere used to have farming as their primary job.

The ecotourism model proposed aims to integrate tourism and farming activities carried out by communities surrounding the KPH area. Inputs from visitors are also considered to accommodate tourists' interest. The selection of plants to be developed in RPH Mangunan is carried out by considering the suitability of biophysical characteristics, preferences of tour operators, tourists/visitors' interests, and the application of rules and regulations in KPH areas. The study uses an approach to the definition of ecotourism based on Blamey (1997) and Weaver (2001), which state that ecotourism includes three components: nature-based activities as the main attractions, learning/education 
as the result of interaction with nature, and the activities are sustainably managed [5], [6].

In several countries, community-based ecotourism began to be recognized as a form of sustainable development that is designed to promote local livelihood, environmental conservation, and culture [7], [8], [9], [10]. However, there is no doubt the development of tourism is also often considered to cause environmental damage mainly due to the development of infrastructures, shifts in cultural values, social and environmental conditions [11], [12]. Therefore the process of designing a management model in community-based ecotourism should engage local communities to suit community needs and ensure community involvement [13]. The logical framework of the study is shown in Figure 1.

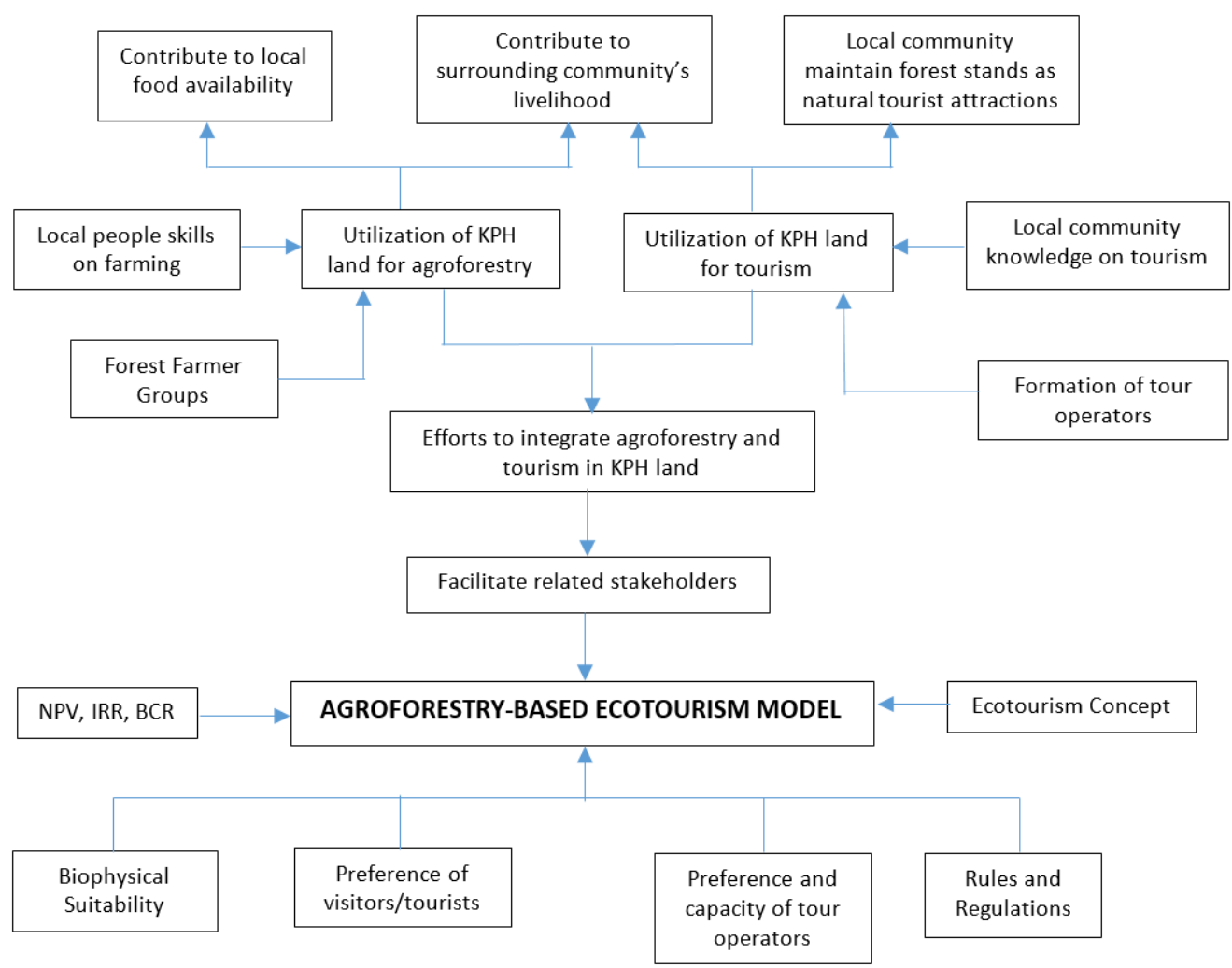

Figure 1. The Logical Framework of the Research 


\subsection{Data Analysis}

Data analysis used is descriptive analysis and financial analysis for the socio-economic data of KPH land users. Financial analysis is an analysis of business feasibility from the owner; in this case, the tour operators. In the financial analysis, the factor to be considered is the cash-flow side, which compares the results of gross revenue or gross sales and the total costs stated in the present value to determine the eligibility or profit criteria of the project business.

The feasibility of a business can be determined by calculating the Net Present Value (NPV), Gross Benefit Cost Ratio (B/C Ratio), and Internal Rate of Return (IRR), as shown in equation (1), (2), and (3).

Net Present Value (NPV)

$$
N P V=\left[\sum_{t=1}^{n} \frac{b_{t}-c_{t}}{(1+i)^{t}}\right]
$$

Gross benefit cost ratio $\mathrm{B} / \mathrm{C}$

$$
\frac{B}{C}=\frac{\sum_{t=1}^{n}\left(\frac{b_{t}}{(1+i) t}\right)}{\sum_{t=1}^{n}\left(\frac{c_{t}}{(1+i)^{t}}\right)}
$$

Internal Rate of Return (IRR)

$I R R=i_{1}+\left[\frac{N P V_{1}}{N P V_{1}-N P V_{2}}\right]\left(i_{2}-i_{1}\right)$

Where:

$B=$ Benefit

$C=$ Cost

$b t=$ Benefit year-t

$c t=$ Cost year- $t$

$\mathrm{t}=$ time (year)

$\mathrm{i}=$ Discount rate 


$$
\begin{aligned}
& N P V_{1}=\text { Positive NPV } \\
& N P V_{2}=\text { Negative NPV } \\
& i_{1}=\text { Discount rate which resulted } N P V_{1} \\
& i_{2}=\text { Discount rate which resulted } N P V_{2}
\end{aligned}
$$

The result of the gross $\mathrm{B} / \mathrm{C}$ calculation is used as a tool to analyze the feasibility of a project, with the following conditions:

gross $\mathrm{B} / \mathrm{C}>1$, the project is feasible, gross $\mathrm{B} / \mathrm{C}=1$, a break-even point is reached, and gross $\mathrm{B} / \mathrm{C}<1$, the project is not feasible.

\section{Results and Discussion}

\subsection{Management of Community-Based Ecotourism in RPH Mangunan}

The establishment of forest farmer groups in RPH Mangunan began in 2007 when the group establishment was based on tumpangsari (intercropping) activities. Intercropping between trees and crops continues until the pine trees begin to grow and produce sap. In 2010 these farmer groups were allowed to take non-timber forest products in the form of pine sap, where at that time the pine trees were 26-year-old. Pine sap collection continued until 2014 with the production of pine resin began to decline as the pine trees are getting older. In 2015, KPH Yogyakarta stopped tapping pine resin for fear of endangering the preservation of pine trees [14].

At the same time, the shade of pine trees began to attract visitors to come to see the beautiful scenery of the pine forest. Since 2013 visitors began to come to Mangunan, and forest farmer groups began to build motorbike parking areas and non-permanent toilet facilities as the number of visitors increased. Then in 2014, the farmer groups proposed a permit to utilize the KPH area for ecotourism and based on regulations, this will be processed unless the forest farmer groups have a legal entity. A cooperative named after Notowono was proposed in 2015 and obtained a legal entity in January 2016. The cooperative began working with Yogyakarta Provincial Government under KPH Yogyakarta to manage tourism in the protected forest of RPH Mangunan starting January 31st, 2017. Notowono cooperative acting as the legal entity that coordinating environmental services offered by the communities so that they can work together with relevant stakeholders such as the Tourism Office, 
the Forestry and Plantation Office in connection with the cooperation of the use of government-owned protected forests to become tourist attractions [15].

The development of ecotourism in RPH Mangunan, where the majority of people's livelihood was farming, is in response to the increasingly uncertain results of agriculture activities under tree plantation. This is in accordance with Budiarti, Suwarto, \& Muflikhati (2013) and Raharjana (2012) which stated that the development of ecotourism is triggered by the uncertain agricultural outputs and there is a demand from the ecological perspective to carry out conservation activities [16], [17].

There are three categories of community members to be able to join in the nine operators: (1) people who have a closed relationship with the existence of forest (having ancestors or family members involved in the existence of the forest); (2) member of forest farmer groups of "intercropping system; (3) Unemployment in the vicinity of the forest area who come from underprivileged families. Within the partnership scheme between cooperatives and local government, the percentage of profit sharing is $25 \%$ for local governments and $75 \%$ for Notowono Cooperative. The proportion of revenue sharing between Notowono cooperative and tour operators is $5 \%$ for the cooperative and $70 \%$ for the nine tour operators to pay all their expenses.

Development of ecotourism in RPH Mangunan involves not only members of the nine tour operators, but also communities around the villages outside the groups. The tourism activities empower women to provide canteens and stalls around the tourist sites. Besides the women's group, there are some families who make handicrafts from bamboo in RPH Mangunan. The bamboo craftsman group has already been formed before the development of tourism in RPH Mangunan. Currently, handicrafts from bamboo haven't been offered as souvenirs in tourism activities. However, with the development of tourism increasingly opened the bamboo handicraft market. Other community groups that also play a role in the development of tourism are art groups that have been established for a long time. One of the tourist attractions is a traditional dance performance called "sendratari," which involves quite lots of art group members.

Tour operators are forms of ecotourism management units under the Notowono cooperative. The division of those units is based on the origin of forest farmer groups and specification on the tourism concepts that are willing to be developed. The roles of these operators are not only as managers for tourism activities but also as area developers. Notowono and the tour operators play important roles in creating economic opportunities for a guest house or homestay owners by making a collaboration that offering a village tour package that includes accommodation. Usually, visitors who are interested in a homestay 
are foreign tourists who want the experience of living in a tourist site along with a lifestyle and interaction with local residents [18]. Bhalla, Coghlan, Bhattacharya, \& Östman (2016) argue that the existence of homestay at Binsar wildlife sanctuary in the Indian Himalayan Region has a positive impact on the development of ecotourism [19]. Ecotourism development in several places such as Dieng, Nglanggeran Ancient Volcano, Grojogan Sewu Tourism Park [12], [17], [20], [21], and outside Indonesia such as at Tafi Atome Monkey protection in Bostwana and Waluma Papua New Guinea [22], [23] has provided economic benefits for the surrounding community.

\subsection{Initial Market Research}

The development of tourism in protection forest areas is limited by regulations to ensure that environmental service management is carried out without damaging the environment and not disturbing the main function of the protection forest. The main function of protection forests is to regulate water systems, prevent flooding, control erosion, prevent seawater intrusion, and maintain soil fertility [24]. Tourism development in protection forests can be carried out in utilization blocks, and only 10 percent of utilization block can be managed for natural tourism activities [24].

Protection forest management in RPH Mangunan by community groups who are part of the tour operators must be always be reminded to comply with the rules applied in protection forests. The limited knowledge of tour operator members in managing tourism is one of the obstacles in tourism managed by communities, as stated by Aseres \& Simane (2016) dan Mensah (2017) [25], [26]. Other factors that become obstacles are financial incapability, awareness of conservation both from operators and visitors, and inadequate infrastructure in the tourism site [25], [27]. The existence of capacity building and support from various stakeholders is needed to improve tourism management [28]. In $\mathrm{RPH}$ Mangunan, efforts to increase capacity building of tour operators are carried out by the Notowono Cooperative, KPH Yogyakarta, and the Yogyakarta Special Region Forestry Service.

Okazaki (2008) identified that the first step in developing community-based tourism is to investigate the existing condition related to local people's involvement and design actions for further improvements [29]. Through the FGD process, an agroforestry-based ecotourism model is proposed. Indirectly, through the process tour operators were reminded again that the tourism activities in KPH Yogyakarta's protection forest are bound by the regulation imposed in protection forests. 
Attractions offered by the nine operators generally are of the same type, namely the view above the height, which is suitable for photo spot. If the attractions offered have similarities between operators, it is feared that visitors to Mangunan will experience burnout. Kim \& Park (2016) study shows that tourists ${ }^{6}$ perceived values on community-based ecotourism in 6 villages of South Korea is influenced by tourist destination appearance [30]. Furthermore, Kim \& Park (2016) argue that this will influence customer satisfaction and competitiveness amongst tourist destinations [30]. Based on interviews with visitors, they proposed ecotourism activities be developed in Mangunan, such as educational tourism, making the process of Yogya's traditional food and drink, outbound, tree planting, and the seedling making of woody plants. Some visitors came with family members, including children, suggested tour operators provide child-friendly attractions.

Almost all tourists who become respondents (98\%) came to RPH Mangunan together with friends/family members/office colleagues. Based on the interview, on average, a domestic tourist spends Rp. 300,000 to come to and while in Mangunan tourist areas. With an average of domestic respondent income of Rp. 2.25 million per month, respondents think that the current ticket price is too cheap. By asking the willingness to pay (WTP), the average WTP is Rp. 8,400. Therefore, there is still a possibility to increase the entrance ticket fee, and the respondent asked for better tourist attractions.

The number of visitors of the three operators in 2017-2019 can be seen in Figure 2. Based on data of year 2017-2019, the average number of tourists to Bukit Pengger, Puncak Becici, and Pinus Sari are 509 thousand, 491 thousand, and 650 thousand visitors/year. If it is assumed that the visitor projection is the average of the three year, then the visitor projection in each operator is 509 thousand, 401 thousand, and 650 thousand respectively. 


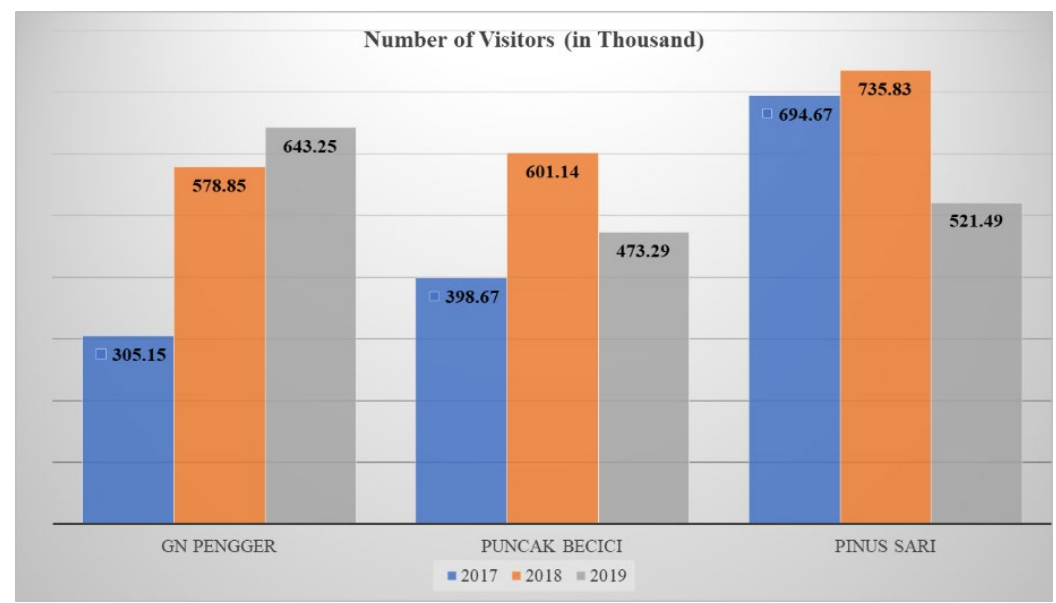

Figure 2. Number of Visitors at Bukit Pengger, Puncak Becici and Pinus Sari in 2017-2019

\subsection{Selection of Tour Operators for the Development of Agroforestry- Based Ecotourism}

For the study, three tour operators were selected to enable the development of agroforestry-based ecotourism. Criteria used in the selection are groups' motivation to plant multipurpose tree species (MPTS) in the KPH area the group managed, availability of area to be planted, and availability of facilities/infrastructure to develop agroforestry-based ecotourism. Based on the selection process, three tour operators that met the three criteria above are Puncak Becici, Pinus Sari, and Bukit Pengger.

Puncak Becici Tour Operator. Puncak Becici is located in a pine-dominated forest covering an area of 97.2 ha, of which the community manages 4.4 hectares. Puncak Becici Tour Operator was initially a forest farmer group whose membership is ex-member of the Becici Asri forest farmer group and their children. Puncak Becici Tour Operator was formed in early 2016, consisting of 56 members and four non-permanent employees (freelance). Members of this group come from Gunung Cilik Village. People who involve in Puncak Becici tour management are not only young men/young women but also oldmen or fathers who were members of the Becici Asri forest farmer group. Those forest farmers are now shifting from pine sap tappers to tour operators. Members of the tour operator are divided into several small teams, including creative, cleanliness, secretariat, and maintenance (of the attractions). Besides the beautiful scenery, Puncak Becici has several photo spots that are 
made from twigs, a performance stage, and a flying fox. Puncak Becici operators' obstacles are the limited capacity of human resources for tourism development and the availability of water. Most of the members of the Puncak Becici group are oldmen with elementary school educational background. The availability of water in Puncak Becici is relatively difficult as they have to buy water and obtain water from bore wells nearby.

Pinus Sari Tour Operator. Pinus Sari Tour Operator manages an area of 9.4 hectares of KPH land. Compared to other operators, Pinus Sari's land is the widest because Pinus Sari is among the initial ones. Like Puncak Becici group members, Pinus Sari tour operator members also come from forest farmer group members and their offsprings. The number of members of this group reaches 60. There are approximately 40-50 members working every day, while freelance workers help 50 members during weekends. The initial capital used in developing tour attractions comes from the group leader and the parking fee. The largest expenditure of Pinus Sari is the salary for the members. The salary received by each person is calculated based on tasks and length of membership in the group. Similar to Puncak Becici, the second significant expenditure is for water purchase.

Bukit Pengger Tour Operator. Bukit Pengger tour operator is located at Dlingo District, Bantul Regency. The pine forest is in the northernmost part, precisely bordering the Pathuk Gunung Kidul District. Bukit Pengger tour operator was formed in 2016 with 41 members. As with the two previous groups, the members of this group were also members of the forest farmer group and their descendants. The area of KPH land managed by this community group is 3.8 ha. The main tourist attraction of Bukit Pengger is photo spots in the form of "Para wara" and "Abi Praya" (triangular shape). Obstacles faced by Bukit Pengger is similar to the previous two groups: water. Another obstacle is the attraction spot made from twigs so that it is easily damaged. Efforts have been made to deal with the water problem is the submission of drilling wells. Tourist spots repairment are carried out continuously or patched every day.

\subsection{Development of Guava and Coffee Plantation}

The type of tree chosen for agroforestry development in the tourist area is multi-purpose trees. In addition to functioning as a woody plant in protected forests, it also provides byproducts and is attractive for agroforestry-based tourism activities. Tree species selected must be under biophysical conditions 
of the RPH Mangunan and coexist with pine, which is the dominant species in the Mangunan protection forest.

Based on group discussion with the three selected operators, guava and coffee plants were the types to be planted in the three operators (Figure 3). The three operators were given guava and coffee seedlings to be planted in the KPH area they managed. The seedlings were planted either in groups or planted on the edge of the area as a barrier to differentiate between tourist areas and nontourist areas. Bukit Pengger tour operator would plant coffee in a somewhat open area to the north of the tourist area, and guava would be planted on the edge of the area as a tourist boundary. Puncak Becici tour group would plant coffee in an area close to Becici's stage, while the guava would be planted in the center of the tourist area near the mosque. Pinus Sari tour group would plant coffee and guava in front of the entrance gate near the parking lot in a particular block type.
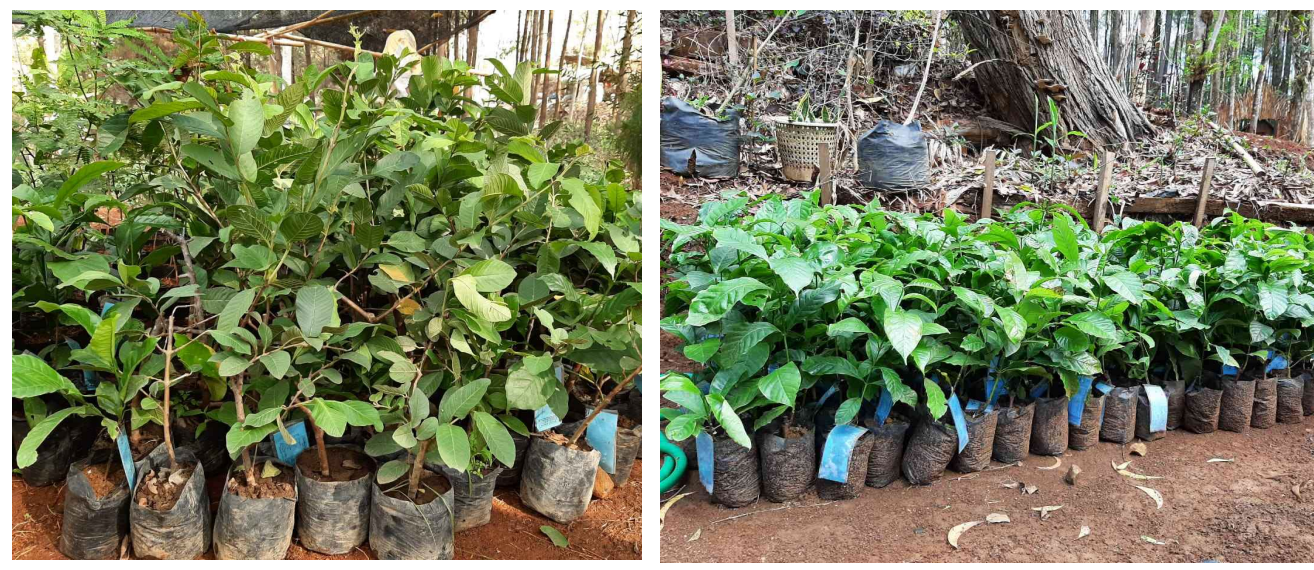

Figure 3. Guava and coffee seeds being planted in RPH Mangunan

The development of agroforestry-based ecotourism will be managed by members of the three selected tour operators. Before becoming a tour operator, the three groups were farmer groups so that more or fewer members have had knowledge and skill in farming. During FGD, representatives from each group had gained knowledge of the cultivation of guava and coffee.

Engagement of surrounding communities allows the involvement of outside the tour operators. Women can participate in the processing of guava and coffee yield into traditional food and drink to highlight local uniqueness. RPH Mangunan can learn from Kusuma Agro Tourism in Batu East Java as an inspiration for post-harvest processing into unique products, where yields of apples and strawberries are processed into juices and sweetmeats, which are 
then would be the main attraction and have their selling points. The youth group will be involved as a freelancer post-harvest handling of guava and coffee. Besides, they can also be involved as tour guides during the holiday season when operators need additional staff, especially giving tourists information about agroforestry in RPH Mangunan. The group of bamboo craftsmen can also be involved as a supplier of the packaging of bamboo for souvenirs, which are processed products from guava and coffee yield.

Based on experience in Borena-Saynt National Park Ethiopia, the development of ecotourism has created employment opportunities and open market access for local handicraft and agricultural products [31]. From a gender perspective, the development of community-based ecotourism in Mangunan also considers a more equitable division of labor, increase income for women, increase self-confidence for women in Mangunan as does the implementation of community-based nature tourism developed in North Vietnam [7].

\subsection{Marketing Plan}

Consumers targeted in agroforestry-based ecotourism business planning are grouped into two groups of tourists, namely mass tourism and special interest tourism. The targeted mass tourism is tourists who buy guava/coffee/coffee bean/coffee powder and their processed products sold by tour operators as souvenirs. In contrast, unique interest tourism targets are tourists interested in tour packages that are being developed.

From interviews to visitors, usually, tour packages are preferred by tourists from out of town or abroad who bring families. Mass tourism is more popular with residents, especially young people. Marketing of products resulting from the cultivation of guava and coffee that support ecotourism activities in RPH Mangunan include:

a. Sales of guava and coffee products directly to visitors. This marketing type is the most conventional way to package the yield of guava and coffee to support ecotourism activities.

b. Sales of processed guava and coffee as souvenirs. For this product, guava and coffee are processed and packaged in such a way according to the characteristics of and local culture. As Sari (2013) states that in the realm of visual communication design, packaging can be one of communication media [32]. Packaging material for souvenirs can also made from traditional materials for example packaging form woven bamboo, so that the products embedded ethnic value and has the impression of "back to nature" massage. 
c. Fruit picking tour packages that are integrated with photo spot so that tourists can enjoy the sensation of fresh fruit that picked himself or processes (fruit juice, coffee brew) directly in the garden.

d. Integration of fruit picking tour packages with other tour packages. The series of fruit picking activities and enjoying its products can be carried out into one activity in a series of cultural tourism, as well as a tour around the pine forest.

The existence of tour guides are needed to provide explanation of the function of protected forests, local wisdom and local culture in managing forests, themes and philosophies raised in the development of tourism, and knowledge on guava and coffee cultivation. The core of this tour package activity is creating a deep impression to tourists. Fiorello \& Bo (2012) studied the development of ecotourism in five countries show that ecotourism not only improves local livelihood but also gives opportunities for local people to introduce culture and traditions [33].

To market agroforestry-based ecotourism activities, several marketing strategies need to be carried out as follows:

a. Promotion

Promotion is carried out using social media, inviting bloggers to have visits and they write reviews on their channels, and establishing cooperation with travel agents, hotels, gift shops, and car rental companies.

b. Building a brand image adjusted to a selected theme and philosophy.

c. Affirmation of personalization/character of tour offered. Efforts should be made to establish character of agroforestry-based ecotourism by raising local culture.

d. Establishment of cooperation with related stakeholders from government, private sectors, and educational institution/universities.

e. Establishment of good relations with customers by providing a means for tourists for giving suggestions and criticism as feedbacks.

f. Provision of information for visitors on the latest information related to tourist activities, access, and costs.

g. Provide interactive two-ways communication between operators and tourists.

\subsection{Financial Analysis and Capital Plan for Development}

Net Present Value (NPV) is the difference between income received and expenses by considering the time value. A positive NPV means that a project is feasible. Internal Rate of Return (IRR) measures how much a project returns 
to investment are invested. The use of NPV and IRR of a project is a method to determine whether a project is feasible or not. In general, a positive NPV and IRR values indicate that a project can be run, and vice versa. NPV and IRR are the methods used to calculate the business feasibility of a project. The use of NPV and IRR calculation results is a reference for interested parties to determine whether a business is feasible or not.

From the calculation, planting guava under a woody stand during a productive cycle of 10 years with a discount factor of $20 \%$ per year, giving a positive NPV of Rp. 5.53 million per ha and IRR of $42 \%$. The calculation shows that the comparison between cost-benefit is 1.18, and positive income starts in the fifth year. Thus based on these results, the development of this guava is feasible (Table 1).

The result of the financial analysis calculation of the development of 200 coffee plants under a woody stands with a productive cycle for 25 years using a discount factor, resulting in an NPV of Rp. 57.46 million per ha and IRR of $69 \%$. A comparison between the projected cost of developing coffee is 10.43 , and positive income starts in the fifth year (Table 1).

Table 1. Financial analysis calculation of guava and coffee plants under woody stand

\begin{tabular}{|l|r|r|r|}
\hline \multicolumn{1}{|c|}{ Plantation } & NPV (Rp/ha) & IRR (\%) & $\begin{array}{c}\text { Year to positive cash } \\
\text { flow (payback period) }\end{array}$ \\
\hline Guava & $5,530,000$ & 42 & 5 \\
\hline Coffee & $57,456,000$ & 69 & 5 \\
\hline
\end{tabular}

Funding is expected to be supported by Notowono cooperative, with soft loan schemes and profit-sharing. In addition, there is a portion of funding fulfilled by the operator independently. To meet funding needs, there is also a possibility of funding from the government and private sector as currently, several companies who have concerns about environmental and community empowerment issues provide funding in the form of Corporate Social Responsibility (CSR).

\subsection{Challenges}

There are several challenges should be anticipated in the development of agroforestry-based ecotourism:

- Competition among tour operators.

Conflict reduction through agreement arrangement between community is one of solutions suggested by Liu et al. (2014) on a case study in China.

- Potential conflicts between tour operators and communities at surrounding villages. 
There is a need to compromise between tour operators and the village community regarding the allocation used for village needs.

- Commitment of tour operators and Notowono cooperative to comply with regulations on using protected forest area.

- Potential damage on RPH Mangunan's protection forest as many visitors come.

Study of Siswantoro, Anggora, \& Sasongko (2012) that identify the carrying capacity of ecotourism in Grojogan Sewu tourism Park would be a good example [21]. Weaver (2001) argue that the major challenge of ecotourism development is how to concentrate visitors to area that has been allocated for ecotourism activities and maintain the remaining area in relatively undisturbed conditions [6].

- Potential accidents occur in tourism area.

At present the pine stands in RPH Mangunan are old enough and this can be dangerous as the trees can collapse any time. An inventory of condition of each tree is needed and if there are trees that are porous then delineation of the area must be avoided by visitors.

- Increase attractiveness of RPH Mangunan tourism so that the number of visitors can be optimal. The development of the attractiveness of the area managed by operators must be unique so that each operator has different characteristics from other operators.

The successful development of community-based ecotourism is strongly supported by the existence of strong community institutions, the relationship between communities and ecosystem values, and the ability to develop activities that provide economical income through tourism activities [23]. There is no community-based ecotourism development template since each community group has different characteristics. However, the challenges faced in developing community-based ecotourism are generally the same, including issues of ownership, participation, monitoring of the impacts, and mutually agreed outcome [23].

\section{Conclusion}

Three tour operators in RPH Mangunan that are ready to develop agroforestry based ecotourism are Bukit Pengger, Puncak Becici, and Pinus Sari. The agroforestry-based ecotourism has a promising market potential considering that the tourist attractions currently in RPH Mangunan are mostly selfphotographed objects, causing boredom to visitors. The agroforestry-based 
ecotourism model to be developed in RPH Mangunan is designed by planting MPTS as part of tourist attractions. Multi-Purpose Tree Species to be planted in tourism areas that are in accordance with biophysical conditions and community preferences to be developed in RPH Mangunan are guava and coffee. The development of agroforestry-based ecotourism enables the achievement of the ecological objective of protected forest management and provides livelihoods for the surrounding community. The results of the financial analysis show that the development of guava and coffee as supporting agroforestry-based ecotourism is feasible. From the calculation, planting guava under a woody stand during a productive cycle of 10 years with a discount factor of $20 \%$ per year, giving a positive NPV of Rp. 5.53 million per ha and an IRR of $42 \%$. The result of the financial analysis calculation of development coffee plants under a woody stands with a productive cycle for 25 years resulting in an NPV of Rp. 57.46 million per ha and IRR of $69 \%$.

Acknowledgments. The authors would like to thank all those who helped during data collection, data processing, and scriptwriting: The Head of KPH Yogyakarta, which has granted the research permit in its area, Center for SocioEconomic Policy and Climate Change Research, which funded this research, Mr. Sukirman, and his staff as well as the Yogyakarta KPH foresters who have assisted in data collection.

\section{References}

[1] Andayani W, Septiana RM, Riyanto S, Supriyatno N. Strategy to Improving Community Economic through on-Farm Agroforestry Using Community Forestry Scheme in KPH Yogyakarta. In: The 3rd International Conference in Agroforestry (ICAF) "Adopting Modern Agroforestry Toward Smart Social Forestry Program. Yogyakarta: Published under licence by IOP Publishing Ltd; 2020.

[2] Balai KPH Yogyakarta. Rencana Pengelolaan Hutan jangka Panjang Kesatuan Pengelolaan Hutan Produksi (RPHJP KPHP) Model Yogyakarta Daerah istimewa Yogyakarta Tahun 2014-2023. Yogyakarta; 2013.

[3] Mayrowani H, Ashari. Perkembangan Agroforestry untuk Mendukung Ketahanan Pangan dan Pemberdayaan Petani Sekitar Hutan. Forum Penelit Agro Ekon. 2011;29(2):83-98.

[4] Charles RL, Munishi PKT, Nzunda EF. Agroforestry as Adaptation Strategy under Climate Change in Mwanga District Kilimanjaro, Tanzania. Int J Environ Prot. 2013;3(11):29-38.

[5] Blamey RK. Ecotourism: The Search for an Operational Definition. J Sustain Tour. 1997;5(2):109-30. 
[6] Weaver DB. Ecotourism as Mass Tourism: Contradiction or Reality. Cornell Hotel Restaur Adm Quarterly. 2001;42(2):104-12.

[7] Tran L, Walter P. Ecotourism, Gender and Developmetn in Northern Vietnam. Ann Tour Res. 2014;44:116-30.

[8] Stone MT 2. Community-Base Ecotourism: A Collaborative Partnerships Perspective. J Ecotourism. 2015;

[9] Liu J, Qu H, Huang D, Chen G, Yue X, Zhao X, et al. The Role of Social Capital in Encouraging Residents' Pro-Environmental Behaviors in Community-Based Ecotourism. Tour Manag. 2014;41:190-201.

[10] Phelan A, Ruhanen L, Mair J. Ecosystem Services Approach for Community-Based Ecotourism: Towards an Equitable and Sustainable Blue Economy. J Sustain Tour. 2020;28(10):1665-85.

[11] Haryanto JT. Model Pengembangan Ekowisata dalam Mendukung Kemanirian Ekonomi Daerah Studi Kasus Provinsi DIY. Kawistara. 2014;4(3):225-300.

[12] Irhamna SA. Dampak Pengembangan Pariwisata Terhadap Perekonomian Masyarakat Sekitar Objek Wisata di Dieng Kabupaten Wonosobo. Econ Dev Anal J. 2017;6(3):3208.

[13] Dewi MHU, Fandeli C, Baiquni M. Pengembangan Desa Wisata Berbasis Partisipasi Masyarakat Lokal di Desa Wisata Jatiluwih Tabanan Bali. Kawistara. 2013;3(2):117226.

[14] Kusmanto DS, Faida LRW. Dampak Wisata Alam Hutan Lindung RPH Mangunan Terhadap Pendapatan Anggota Koperasi Notowono. Universitas Gajah Mada; 2018.

[15] Marlinda M. Pemberdayaan Masyarakat Sukorame oleh Koperasi Notowono dalam Membangun Destinasi Wisata Baru. Universitas Islam Negeri Sunan Kalijaga; 2019.

[16] Budiarti T, Suwarto, Muflikhati I. Pengembangan Agrowisata Berbasis Masyarakat pada Usahatani Terpadu Guna Meningkatkan Kesejahteraan Petani dan Keberlanjutan Sistem Pertanian. J Ilmu Pertan Indones. 2013;18(3):200-7.

[17] Raharjana DT. Membangun Pariwisata Bersama Rakyat: Kajian Partisipasi Lokal dalam membangun Desa Wisata di Dieng Plateau. Kawistara. 2012;2(3):225-37.

[18] Kontogeorgopoulos N, Churyen A, Duangsaeng V. Homestay Tourism and the Commercialization of the Rural Home in Thailand. Asia Pacific J Tour Res 21(8) 836861. 2015;20(1):29-50.

[19] Bhalla P, Coghlan A, Bhattacharya P, Östman A. Homestay Contribution to Community-Based Ecotourism in the Himalayan Region of India. Tour Recreat Res. 2016;41(2):213-28.

[20] Rosida I. Partisipasi Pemuda dalam Pengembangan Kawasan Ekowisata dan Implikasinya terhadap Ketahanan Masyarakat Desa. J Ketahanan Nasional. 2014;20(2):67-77.

[21] Siswantoro H, Anggora S, Sasongko DP. Strategi Optimasi Wisata Massa di Kawasan Konservasi Taman Wisata Alam Grojogan Sewu. J Ilmu Lingkung. 2012;10(2):100-10.

[22] Afenyo, E.A. Amuquandoh FE 2. Who Benefits from Community-based Ecotourism Development? Insights from Tafi Atome, Ghana. Tour Plan Dev. 2014;11(2):179-90. 
[23] Sakata B, Prideaux B. An Alternative Approach to Community-Based Ecotourism: A Bottom-Up Locally Initiated Non-Monetised Project in Papua New Guinea. J Sustain Tour. 2013;

[24] Menteri Kehutanan. Peraturan Menteri Kehutanan Republik Indonesia Nomor P.22/Menhut-II/2012 tentang Pedoman Kegiatan Usaha Pemanfaatan Jasa Lingkungan Wisata Alam pada Hutan Lindung. 2012.

[25] Aseres SA, Simane B. Development of Community-Based Ecotourism, A Case of Choke Mountains and Its Environs, Ethiopia: Challenges and Opportunities. J Tour Hosp Sport. 2016;16:14-21.

[26] Mensah I. Benefits and Challenges of Community-Based Ecotourism in Park-Fringe Communities: The Case of Mesomagor of Kakum National Park, Ghana. Tour Rev Int. 2017;21:81-98.

[27] Menbere IP, Menbere TP. Opportunities and Challenges for Community-Based Ecotourism Development: A Case Study in Dinsho and Goba Woredas, Southeast Ethiopia. Int J Ecol Ecosolution. 2017;4(1):5-16.

[28] Atanga RA. Stakeholder Views on Sustainable Community-Based Ecotourism: A Case of the Paga Crocodile Ponds in Ghana. Geoj Tour Geosites. 2019;25(2):321-33.

[29] Okazaki E. A Community-Based Tourism Model: Its Conception and Use. J Sustain Tour. 2008;16(5):511-9.

[30] Kim K, Park D. Relationships Among Perceived Value, Satisfaction, and Loyalty: Community-Based Ecotourism in Korea. J Travel Tour Mark. 2016;34(2):171-91.

[31] Eshetu AA. Development of Community Based Ecotourism in Borena-Saynt National Park, North Central Ethiopia: Opportunities and Challenges. J Hosp Manag Tour. 2014;5(1):1-12.

[32] Sari NLDID. Elemen visual kemasan sebagai strategi komunikasi produk. J Komun Profetik. 2013;6(1):43-52.

[33] Fiorello A, Bo D. Community-Based Ecotourism to Meet the New Tourist's Expectations: An Exploratory Study. J Hosp Mark Manag. 2012;21:758-78. 